\title{
Pengembangan Media Pembelajaran Berbasis Sparkol Videoscribe pada Mata Pelajaran Bahasa Inggris
}

\author{
Rafiud Ilmudinulloh \\ Prodi Pendidikan Agama Islam, Insitut Agama Islam Negeri Manado, Manado, Indonesia \\ email: rafiud.ilmudinulloh@iain-manado.ac.id
}

\begin{abstract}
Abstrak
Pembelajaran abad 21 mendorong guru untuk meningkatkan kompetensi teknologi. Penelitian ini bertujuan untuk mengembangkan media pembelajaran berbasis Sparkol Videoscribe yang layak digunakan pada mata pelajaran bahasa Inggris, oleh karenanya metode penelitian yang digunakan adalah Research and Development (R\&D). Model pengembangan dalam penelitian ini diadaptasi dari Sadiman yang meliputi tahapan - tahapan: 1) Identifikasi Kebutuhan, 2) Perumusan Tujuan, 3) Perumusan Butir-Butir Materi, 4) Perumusan Instrumen Penilaian, 5) Penulisan Naskah Media, 6) Uji Coba, 7) Revisi, dan 8) Siap Produksi. Jenis data terdiri dari data verbal, dan data numerik. Instrumen penelitian terdiri dari wawancara terbuka, observasi dan angket. Teknik analisis yang digunakan adalah deskriptif kualitatif dan statistik deskriptif. Hasil penelitian menunjukkan bahwa media pembelajaran berbasis Sparkol Videoscribe memenuhi kriteria kelayakan setelah menyelesaikan tahapan tahapan pengembangan adaptasi Sadiman. Ahli materi dan media memberikan peniliaan dengan kualifikasi baik dan tidak perlu direvisi. Dan uji coba lapangan mendapat penilaian dengan kualifikasi sangat baik dan tidak perlu direvisi.
\end{abstract}

Kata Kunci: Media Pembelajaran, Sparkol Videoscribe, Bahasa Inggris.

\begin{abstract}
21 st century learning encourages teachers to improve technological competence. This study aims to develop learning media based on Sparkol Videoscribe which is suitable for use in English subject, therefore the used research method is Research and Development $(R \& D)$. The developing model is adapted from Sadiman including stages: 1) need identification, 2) objective formulation, 3) formulation of material items, 4) formulation of assessment instruments, 5) creating of media script, 6) experiment, 7) revision, \& 8) Production. Data types are verbal dan nominal. Research instruments are open interviews, observation, and questionnaires. Used analysis techniques are descriptive qualitative and descriptive statistics. Research result shows sparkol videoscribe-based learning media meets with the eligibility of criteria after completing the stages of sadiman-adapted developing. Material and media experts gave the score at a good qualification without revision. And field experiment got the score at a very good qualification without revision.
\end{abstract}

Keywords: Learning Media, Sparkol Videoscribe, English Subject 


\section{PENDAHULUAN}

Eksistensi studi teknologi pendidikan telah membawa dampak yang sangat signifikan terhadap perkembangan dunia pembelajaran. Kehadiran berbagai inovasi dalam dunia pembelajaran tidak lepas dari teori dan praktik dalam domain teknologi pendidikan yang sistematis, integratif dan humanis. Konsep pembelajaran populer seperti E-learning, M-Learning, Online Learning, dan Virtual Learning sejatinya merupakan turunan dari program korespondensi atau pembelajaran jarak jauh yang pertama kali diterapkan di Universitas Chicago pada akhir tahun 1980-an oleh seorang teknolog pembelajaran yang bernama Whilliam R. Harper. Pengembangan media pembelajaran yang paling muktahir pun sampai hari ini masih berpegang pada hasil pemikiran klasik dari tokoh - tokoh seperti Brunner, Skinner, Gagne, Bringgs, Edgar Dale, dan Schramm. Setidaknya terdapat tiga tantangan besar bagi praktisi teknologi pendidikan untuk menghasilkan produk - produk pembelajaran yang adaptif, akomodatif dan aplikatif. Adaptif berarti mampu menyinkronkan diri dengan tipe/gaya belajar siswa yang berbeda, akomodatif artinya mampu menampung berbagai kebutuhan belajar siswa, dan aplikatif berarti dapat dengan mudah digunakan oleh pengguna atau user friendly.

Tatangan di atas sejalan dengan tuntutan kompetensi pembelajaran abad 21, di mana guru dan siswa harus dibekali dengan technological competency yang mampu mendasari terintegrasinya ICT (Information and Communication Technologies) dalam sekolah, kehidupan dan perkembangan ekonomi (Pineida, 2011). Technological Competency meliputi kemampuan guru dalam mencari, menciptakan, memilih, memanfaatkan teknologi pembelajaran yang efektif dan efisien (Nessipbayeva, 2019). Sedangkan siswa memiliki kemampuan dalam mengakses, memanfaatkan dan mengevaluasi informasi dan sumber belajar (Zubaidah, 2016). Jika melihat Data terkini, nilai rata - rata Uji Kompetensi Guru (UKG) nasional masih dibawah angka 65 (npd.kemdikbud.go.id). Terkhusus, pada kemampuan TIK (Teknologi Informasi dan Komunikasi) kompetensi guru masih dalam kategori cukup dan perlu ditingkatkan (Batubara, 2017), dan untuk pemanfaatan IT (Information Technlology) masih rendah (Rahim et al., 2019).

Belum tuntas dengan persoalan penguasaan kompetensi, guru masih diperhadapkan dengan masalah - masalah seperti rendahnya minat, motivasi, hasil belajar, efektifitas, efisiensi dll. Di salah satu sekolah yang peneliti observasi masih banyak siswa yang merasa bosan karena guru menggunakan metode pembelajaran yang konvensional dan tidak adanya keterlibatan media pembelajaran dalam meningkatan fokus dan perhatian siswa pada saat proses pembelajaran berlangsung sehingga dapat berpengaruh terhadap rendahnya capaian belajar. Dengan permasalahan yang sama, beberapa praktisi dan peneliti seperti (Wulandari, 2016), (Pamungkas et al., 2018), (Dwi Pratiwi, 2016) dan (Fransisca, 2018) mencoba melakukan pengembangan terhadap media pembelajaran menggunakan sparkol videoscribe untuk mencapai tujuan pembelajaran. Sparkol Videoscribe merupakan software komersil yang mampu menghasilkan whiteboard animation video melalui proses selecting, editing, setting, dan converting.

Videoscribe dikembangkan oleh perusahaan software ternama asal Inggris Sparkol Inc pada tahun 2012. Software ini telah membantu banyak orang untuk menyampaikan pesan secara menarik dan mengesankan melalui gambar, teks, dan animasi yang dikemas dalam video. Videoscribe memiliki keunggulan dalam menyampaikan pesan secara animatif, layaknya seorang guru yang menjelaskan sesuatu di papan tulis dengan gambar dan tulisan. Keunggulan itu sangat bermanfaat dalam berkomunikasi baik secara visual maupun verbal, terlebih di era digital konten. Dalam dunia pendidikan dan pembelajaran, seorang guru dapat mengemas materi ajar dalam bentuk Videoscribe yang bermakna, menarik dan menyenangkan sehingga dapat meningkatkan motivasi dan prestasi belajar siswa (Pamungkas et al., 2018). Dosen dan mahasiswa juga dapat memanfaatkan Videoscribe untuk mempresentasikan karya ilmiahnya agar lebih menarik dan mudah dipahami.

Dalam rangka mendukung penguasaan kompetensi teknologi pada guru, melakukan penelitian lanjutan terhadap penelitian - penelitian sebelumnya dan mengatasi permasalahan yang terjadi di

60 | Pengembangan Media Pembelajaran Berbasis Sparkol Videoscribe pada Mata Pelajaran Bahasa Inggris 
lapangan, khususnya pada mata pelajaran Bahasa Inggris di mana masalah tersebut perlu segera untuk ditangani, maka peneliti bertujuan untuk melakukan pengembangan media pembelajaran berbasis sparkol videoscribe pada mata pelajaran bahasa Inggris yang berlokasi di Madrasah Tsanawiyah Negeri Model Makassar.

\section{METODE PENELITIAN}

Tujuan penelitian ini adalah menghasilkan produk berupa media pembelajaran berbasis videoscribe yang layak untuk digunakan pada mata pelajaran bahasa Inggris di MTsN Model Makassar, oleh karenanya metode penelitian yang digunakan adalah Research and Development (R\&D). Penelitian pengembangan merupakan suatu analisis sistematik terhadap desain, pengembangan dan evaluasi, terhadap proses dan produk pembelajaran yang harus memenuhi kriteria efektifitas, validitas, dan kepraktisan (Richey, R. C. \& Seels, 1994). Model pengembangan dalam penelitian ini diadaptasi dari Sadiman et al., (2012) yang meliputi tahapan - tahapan: 1) Identifikasi Kebutuhan, 2) Perumusan Tujuan, 3) Perumusan Butir-Butir Materi, 4) Perumusan Instrumen Penilaian, 5) Penulisan Naskah Media, 6) Uji Coba, 7) Revisi, dan 8) Siap Produksi. Salah satu yang menjadi pertimbangan peneliti untuk menggunakan model Sadiman dkk adalah desain pengembangan sangat relevan digunakan untuk menghasilkan produk pengembangan berupa video pembelajaran. Hal tersebut dapat dilihat dari tiap tahapan pengembangan yang ditunjukkan pada Gambar 1, terutama di tahap kelima yakni penulisan naskah, di mana Sadiman sendiri menjelaskan dalam bukunya dengan contoh naskah video pembelajaran.

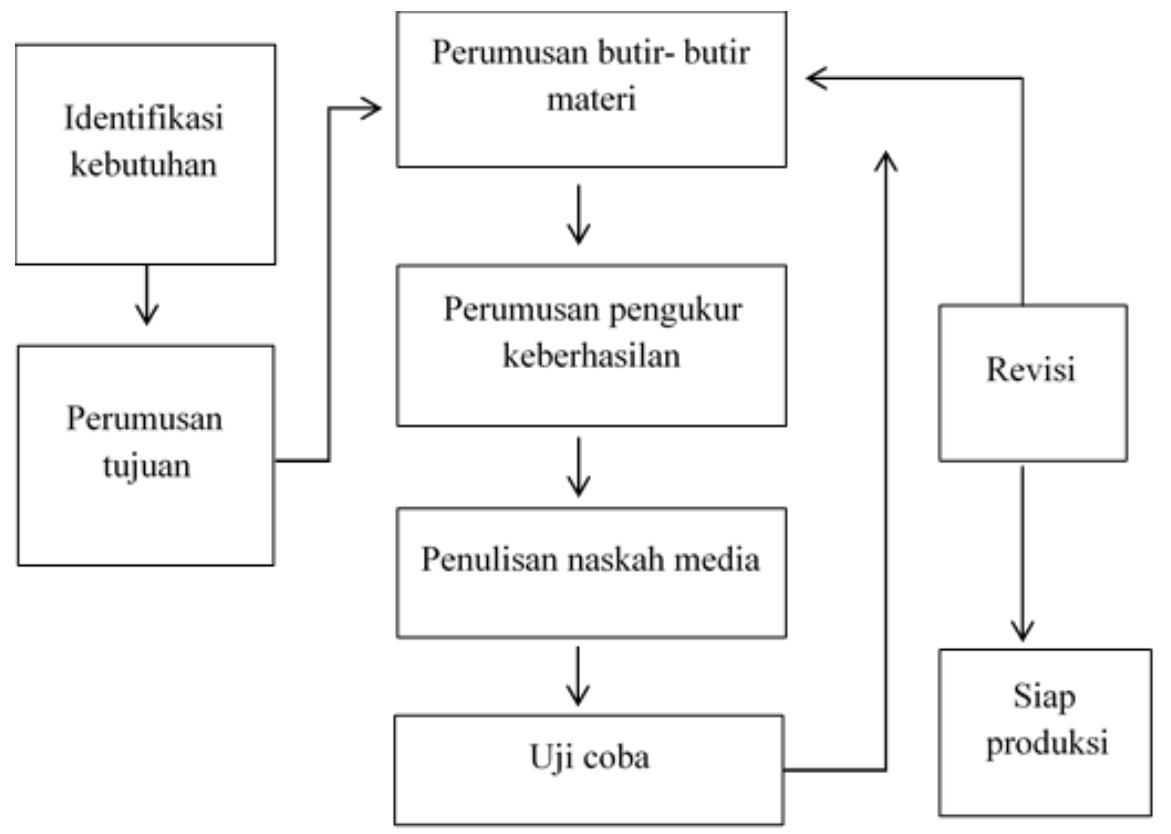

Gambar 1. Model Pengembangan Adaptasi Sadiman et al., (2012)

Penelitian ini dilaksanakan di MTsN Model (Madrasah Tsanawiyah Negeri) Makassar di kelas VII-7 pada mata pelajaran Bahasa Inggris dengan jumlah siswa 40 orang. Media pembelajaran diproduksi setelah memperoleh hasil identifikasi kebutuhan, hasil rumusan tujuan, hasil rumusan materi dan naskah media. Tahap produksi meliputi 1) selecting/memilih, 2) editing/mengubah, 3) setting/mengatur dan 4) rendering/penyatuan. Desain uji coba melibatkan ahli materi, ahli media, guru mata pelajaran dan sejumlah siswa. Jenis data terdiri dari data verbal seperti saran, masukan, kritik, komentar dan data nomerik seperti hasil pengisian instrumen uji coba media. Instrumen penelitian terdiri dari wawancara terbuka, observasi dan angket. Angket meliputi angket identifikasi kebutuhan, angket 
validasi materi/konten, media, dan uji coba siswa dan guru. Terdapat dua teknik analisis yang digunakan yakni deskriptif kualitatif dan statistik deskriptif. Deskriptif kualitatif digunakan untuk mengintrepretasikan masukan, tanggapan, kritik dan saran perbaikan yang terdapat pada angket, sedangkan statistik deskriptif digunakan untuk memberikan makna terhadap hasil perolehan skor pada angket. Persamaan (1) yang digunakan untuk menghitung presentasi penilaian terhadap media yang telah dikembangkan adalah presentase yang dicari (p), frekuensi dari setiap jawaban (f), dan jumlah skor ideal (n).

$$
p=\frac{f}{n} 100 \%
$$

Sumber: Sugiyono (2012: 95)

Konversi tingkat Pencapaian dengan Skala 3 dan Skala 2 dapat dilihat pada Tabel 1 dan Tabel 2 yang digunakan untuk memaknai angket identifikasi kebutuhan pada aspek proses pembelajaran dan penggunaan media pembelajaran oleh guru.

Tabel 1. Konversi Tingkat Percapaian dengan Skala 3

\begin{tabular}{ccc}
\hline Kualifikasi & & Tingkat Pencapaian \\
\hline Cukup & Jika skor & $>=66,7 \%$ \\
\hline Rendah & Jika skor & $<66,7 \%$ \\
\hline \multicolumn{3}{c}{ Sumber: Sugiyono (2012: 95) }
\end{tabular}

Tabel 2. Konversi Tingkat Pencapaian dengan Skala 2

\begin{tabular}{ccc}
\hline Kualifikasi & \multicolumn{2}{c}{ Tingkat Pencapaian } \\
\hline Cukup & Jika skor & $>=50 \%$ \\
\hline Rendah & Jika skor & $<50 \%$ \\
\hline \multicolumn{3}{r}{ Sumber: Sugiyono (2012: 95) }
\end{tabular}

Konversi Tingkat Pencapain dengan Skala 5 pada Tabel 3 digunakan pada angket ahli materi, media, dan uji coba siswa dan guru digunakan untuk menguji kelayakan media pembelajaran yang telah dikembangkan pada mata pelajaran bahasa Inggris.

Tabel 3. Konversi Tingkat Percapaian dengan Skala 5

\begin{tabular}{|c|c|c|}
\hline $\begin{array}{c}\text { Tingkat } \\
\text { Pencapaian }\end{array}$ & Kualifikasi & Keterangan \\
\hline $90 \%-100 \%$ & Sangat Baik & Tidak Perlu Direvisi \\
\hline $75 \%-89 \%$ & Baik & Tidak Perlu Direvisi \\
\hline $65 \%-74 \%$ & Cukup & Direvisi \\
\hline $55 \%-64 \%$ & Kurang & Direvisi \\
\hline $0 \%-54 \%$ & Sangat Kurang & Direvisi \\
\hline \multicolumn{3}{|r|}{ Sumber: Tegeh \& Kirana (2010) } \\
\hline
\end{tabular}

Dari tabel di atas, maka media pembelajaran yang valid dan tidak memerlukan revisi apabila nilai tingkat validasi media tersebut $>=75 \%$, apabila $<75 \%$ maka media pembelajaran tersebut memerlukan revisi. Sedangkan untuk lembar komentar, hasil tanggapan, kritik dan saran dari validator akan dijadikan bahan 
pertimbangan untuk revisi media pembelajaran. Apabila masukan dari validator tersebut sama maka masukan dari validator akan diterima. Sedangkan apabila ada berbedaan dari validator maka peneliti akan mempertimbangkan apakah saran tersebut diterima atau ditolak.

\section{HASIL DAN PEMBAHASAN}

Hasil penelitian merujuk pada langkah - langkah yang terdapat dalam model pengembangan adaptasi Sadiman (2012). Pertama, Identifikasi kebutuhan meliputi gambaran kondisi proses pembelajaran, spesifikasi media pembelajaran, dan materi pembahasan. Dari hasil observasi dan analisis terhadap angket yang tersebar, diperoleh gambaran bahwa guru telah menggunakan media gambar/cetak dalam proses pembelajaran, namun sebagian besar siswa masih meragukan dayak tarik media gambar/cetak. Jawaban siswa terkait dengan pertanyaan tentang daya tarik media gambar/cetak yang digunakan oleh guru dapat dilihat pada Tabel 4 berikut.

Tabel 4. Distribusi Jawaban Siswa tentang Daya Tarik Media Gambar/Cetak

\begin{tabular}{llccc}
\hline Kategori & Skor & $\mathbf{F}$ & $\mathbf{P}$ & $\mathbf{S} * \mathbf{F}$ \\
\hline Ya & 3 & 17 orang & $42,5 \%$ & 51 \\
\hline Kadang - Kadang & 2 & 19 orang & $47,5 \%$ & 38 \\
\hline Tidak & 1 & 4 orang & $10, \%$ & 4 \\
\hline Jumlah & & 40 orang & $100 \%$ & 93 \\
\hline
\end{tabular}

Jumlah total keseluruhan skor yang diperoleh dari 40 orang siswa pada pertanyaan ini adalah 93 atau 77,5\% dari total keseluruhan skor. Merujuk pada tabel konversi, skor 93 atau 77,5\% masuk dalam kategori cukup karena presentasi skor $>66,7 \%$. Namun di sisi lain, siswa tetap menginginkan media selain media gambar/cetak.

Tabel 5. Distribusi Jawaban Siswa tentang Kebutuhan Media selain Media Gambar/Cetak

\begin{tabular}{llccc}
\hline Kategori & Skor & $\mathbf{F}$ & $\mathbf{P}$ & $\mathbf{S} * \mathbf{F}$ \\
\hline Ya & 3 & 35 orang & $87 \%$ & 105 \\
\hline Kadang - Kadang & 2 & 1 orang & $2 \%$ & 2 \\
\hline Tidak & 1 & 4 orang & $10 \%$ & 4 \\
\hline Jumlah & & 40 orang & $100 \%$ & 111 \\
\hline
\end{tabular}

Tabel 5 di atas menunjukan tingginya permintaan siswa terhadap media selain media gambar/cetak dengan tingkat presentasi yang mencapai 87\%. Identifikasi terkait kriteria media pembelajaran dilakukan dengan mengajukan tujuh pertanyaan tentang multimedia, dan diperoleh hasil bahwa siswa menginginkan media pembelajaran yang memuat, teks, gambar, suara, dan animasi dalam format cerita/percakapan dengan presentase rata - rata $92 \%$ atau $>66,7 \%$. Berdasarkan hasil analisis data terhadap beberapa materi bahasa inggris yang dibutuhkan siswa, diperoleh gambaran secara umum bahwa siswa membutuhakan materi bahasan mengenai kata sifat, kalimat deskripsi, dan kata ganti benda karena sebagian besar siswa belum memahami cara mengungkapkan pertanyaan dan pernyataan tentang benda, mendeskripsikan benda, dan menggunakan kata ganti benda.

Kedua, Tujuan pembelajaran dirumuskan berdasarkan Standar Kompetensi dan Kompetensi Dasar yang tertera dalam silabus mata pelajaran bahasa inggris kelas VII semester II di MTsN Model Makassar yakni 1) Siswa mampu mendengarkan ungkapan untuk menanyakan benda, 2)Siswa mampu mengidentifikasi struktur ungkapan, 3) Siswa mampu mengidentifikasi nama - nama benda berserta karakteristiknya, 4) Siswa mampu mendeskripsikan benda yang dipilih dan 5) Siswa mampu menggunakan struktur teks dan bahasa yang baik dan benar. Rumusan tujuan di atas telah disusun dalam bentuk Rencana Pelaksanaan Pembelajaran (RPP) selama tujuh pertemuan. Ketiga, butir - butir materi 
meliputi parts of speech yang terdiri dari adjective dan possesive pronoun yang kemudian dimasukan dalam tema Describing Things. Keempat, alat ukur keberhasilan berupa angket identifikasi kebutuhan, angket uji validasi ahli materi, angket uji validasi media, dan angket uji lapangan yang sasaranya guru dan siswa sebagai objek. Kelima, naskah media meliputi identitas program, sinopsis, naskah visual dan audio berserta efek dan angle pengambilan gambar mulai dari awal hingga akhir program.

Tabel 6. Distribusi Jawaban Ahli Media, Ahli Materi dan Guru dalam Angket Penilaian

\begin{tabular}{|c|c|c|c|c|c|c|c|c|c|c|c|c|c|c|c|c|c|c|}
\hline \multirow{2}{*}{ No } & \multirow{2}{*}{ Nama } & \multicolumn{13}{|c|}{ Pertanyaan Angket } & \multirow{2}{*}{$\mathbf{X}$} & \multirow{2}{*}{ X1 } & \multirow{2}{*}{$\%$} & \multirow{2}{*}{ Kategori } \\
\hline & & 1 & 2 & 3 & 4 & 5 & 6 & 7 & 8 & 9 & 10 & 11 & 12 & 13 & & & & \\
\hline 1 & $\begin{array}{l}\text { Ahli } \\
\text { Materi }\end{array}$ & 5 & 5 & 4 & 4 & 3 & 3 & 4 & 4 & 4 & 3 & 4 & & & 43 & 55 & 78 & Baik \\
\hline 2 & $\begin{array}{l}\text { Ahli } \\
\text { Media }\end{array}$ & 4 & 5 & 4 & 5 & 4 & 5 & 5 & 4 & 4 & 4 & 4 & 5 & 4 & 57 & 65 & 87 & Baik \\
\hline 3 & Guru & 4 & 5 & 5 & 4 & 5 & 5 & 5 & 5 & 5 & 4 & 4 & 5 & 5 & 61 & 65 & 93 & $\begin{array}{l}\text { Sangat } \\
\text { Baik }\end{array}$ \\
\hline
\end{tabular}

Keenam, Tabel 6 menunjukkan hasil uji coba meliputi validasi ahli materi, ahli media, guru dan uji coba lapangan. Ahli Materi, Nasrullah, M.Pd, memberikan nilai 43 atau 78\% dari total skor keseluruhan yang jika disandingkan dengan tabel konversi maka masuk dalam kategori baik (tanpa revisi) dan menambahkan catatan pada kolom saran agar kosakata kegiatan warming up harus berkaitan dengan isi percakapan, matari, dan tugas. Ahli Media, Dr. Pattaufi, S.Pd, M.Si, memberikan nilai 57 atau $87 \%$ dari total skor yang jika dimasukkan dalam tabel konversi masuk dalam kategori baik (tanpa revisi) dengan catatan:

"medianya sudah layak digunakan dalam proses penelitian, hanya saja yang perlu ditekankan adalah bagaimana guru menggunakan media tersebut pada saat proses pembelajaran. Oleh karena itu peneliti harus komunikasi dan melatih guru yang akan mengajar dalam menggunakan media ini."

Guru mata pelajaran, Hj, A. Roslan Sinrang, S.Pd, memberikan nilai 61 atau $93 \%$ dari total keseluruhan skor yang jika dimasukan dalam tabel konversi ada dalam kategori sangat baik (tanpa revisi) dengan catatan:

"Media sudah cukup baik. Tapi teks/tulisannya agak kabur-kabur, coba diganti fontnya. Materi terlalu kompleks, coba disederhanakan. Suara narator masih kasar, harus diperhalus lagi."

Setelah melakukan perbaikan terhadap masukan dan saran ahli materi, ahli media dan guru, media pembelajaran sparkol videoscribe diujicobakan di kelas VII-7 selama tujuh pertemuan dan diakhir pertemuan siswa diminta untuk mengisi angket penilaian media pembelajaran. Berikut adalah hasil ujicoba lapangan yang ditunjukkan pada Tabel 7.

Tabel 7. Hasil Penilaian Uji Coba Lapangan

\begin{tabular}{ccccc}
\hline Tingkat Pencapaian & K & F & $\%$ & Ket \\
\hline $90 \%-100 \%$ & Sangat Baik & 28 & 70 & Tidak Perlu Direvisi \\
\hline $75 \%-89 \%$ & Baik & 11 & 27,5 & Tidak Perlu Direvisi \\
\hline $65 \%-74 \%$ & Cukup & 1 & 2,5 & Direvisi \\
\hline $55 \%-64 \%$ & Kurang & 0 & 0 & Direvisi \\
\hline $0 \%-54 \%$ & Sangat Kurang & 0 & 0 & Direvisi \\
\hline
\end{tabular}




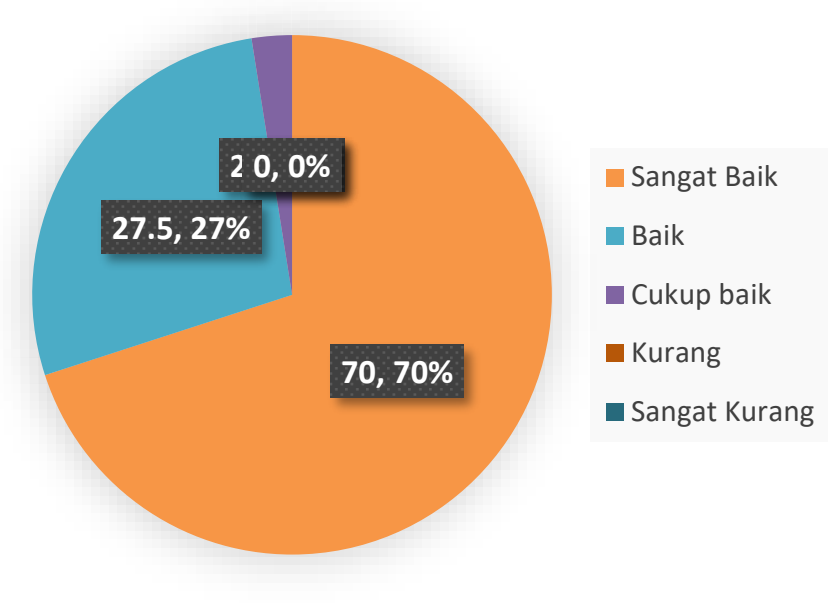

Gambar 2. Hasil Penilaian Uji Coba Lapangan

Hasil uji coba lapangan memperoleh nilai kelayakan yang cukup tinggi dari responden dengan rincian $70 \%$ responden menjawab media sangat baik, 27,5\% menjawab baik, dan 2,5\% menjawab cukup baik. Hal ini diilustrasikan dalam Gambar 2. Berikut adalah komentar yang diberikan oleh responden dalam kolom kritik dan saran.

Tabel 8. Saran dan Kritik dari Responden

\begin{tabular}{cl}
\hline No Absen & \multicolumn{1}{c}{ Komentar } \\
\hline $\mathbf{2}$ & $\begin{array}{l}\text { Sangat berterima kasih atas media yang telah dibuat karena dapat membantu } \\
\text { saya dalam memahami pelajaran }\end{array}$ \\
\hline $\mathbf{3}$ & Kesesuaian gambar dan tempo waktu mesti diperbaiki \\
\hline $\mathbf{5}$ & Bagus kak, animasinya cocok dalam mata pelajaran bahasa Inggris \\
\hline $\mathbf{6}$ & Sangat baik karena menjelaskan cara menggunakan media \\
\hline $\mathbf{8}$ & $\begin{array}{l}\text { Saya tertarik atas media yang telah dibuat karena memiliki pembelajaran } \\
\text { yang tepat dan banyak animasi yang menarik }\end{array}$ \\
\hline $\mathbf{1 0}$ & Saya harap dapat meningkatkan keahlianku dalam belajar bahasa inggris \\
\hline $\mathbf{1 3}$ & Saya tertarik semoga dapat meningkatkan keahlianku dalam bahasa inggris \\
\hline $\mathbf{1 6}$ & Cukup baik, karena mengajarkan tentang sifat adjective \\
\hline $\mathbf{1 7}$ & $\begin{array}{l}\text { Cukup baik, menarik, mudah dipahami karena memperlihatkan kata dan } \\
\text { objeknya }\end{array}$ \\
\hline $\mathbf{1 9}$ & Sangat bagus \\
\hline $\mathbf{2 0}$ & Pangat baik \\
\hline $\mathbf{2 3}$ & Penjelasan media terlalu cepat, suara narator tidak terlalu jelas. Saran: \\
\hline $\mathbf{2 7}$ & Media sudah baik, saya menyukai deskripsinya \\
\hline $\mathbf{3 0}$ & $\begin{array}{l}\text { Sedia sudah baik, saya menyukai deskripsinya } \\
\text { ini bisa saja dipresentasikan kepada guru-guru untuk mengajar muridnya } \\
\text { menggunakan media }\end{array}$ \\
\hline $\mathbf{3 5}$ & $\begin{array}{l}\text { Askum.wr.wb kekurangannya cuma suaranya saja. Suara kayaknya pecah } \\
\text { ditambah musik yang baik mungkin lebih menarik }\end{array}$ \\
\hline $\mathbf{4 0}$ & Suaran narator pada media tidak terlalu jelas \\
\hline
\end{tabular}


Ketujuh, revisi kembali dilakukan setelah ujicoba lapangan dengan menyaring komentarkomentar yang diberikan responden pada kolom saran dan kritik seperti memperjelas suara narator, timming gambar dan suara, dan beberapa pembahasan materi yang terlalu cepat. Delapan, media pembelajaran berbasis sparkol videoscribe diproduksi dalam bentuk paket berupa kepingan CD dan pedoman penggunaan dan didistribusikan ke sekolah untuk digunakan sebagai media pengajaran.

\section{Pembahasan}

Media pembelajaran berbasis Sparkol Videoscribe sudah memenuhi kriteria kelayakan setelah menyelesaikan tahapan - tahapan pengembangan adaptasi Sadiman dkk, (2012) yakni 1) Identifikasi Kebutuhan, 2) Perumusan Tujuan, 3) Perumusan Butir-Butir Materi, 4) Perumusan Instrumen Penilaian, 5) Penulisan Naskah Media, 6) Uji Coba, 7) Revisi, dan 8) Siap Produksi. Media pembelajaran mendapatkan poin sempurna dari ahli materi mengenai kesesuaian media dengan materi, konten, dan tujuan pembelajaran. Menurut (Dwijayani, 2019) media pembelajaran yang tetap merupakan hasil sinkronisasi antara kebutuhan dan tujuan pembelajaran. Selain itu, media harus berisikan materi dan konten yang sesuai dengan taraf berfikir siswa (Sudjana \& Rivai, 2011). Media pembelajaran juga memperoleh poin sempurna dari ahli media terkait pemilihan gambar, teks, konsistensi efek animasi, dan kejelasan pesan yang menjadi inti pembahasan. Media pembelajaran visual yang baik setidaknya menuhi kriteria keterbacaan (readability), mudah dilihat (visibility), mudah dimengerti (legibility), dan komposisi yang baik (Pauwels, 2015). Kriteria readability meliputi pemilihan jenis dan ukuran font, kriteria visibility meliputi pemilihan warna teks dan latar, dan kriteria legibility meliputi kemudahan orang dalam memahami pesan dalam media (Sulistyono, 2016). Dari perspektif guru mata pelajaran, media yang dikembangkan mendapatkan poin sempurna terkait kesesuaian materi dengan konsep dialog yang digunakan pada media, kejelasan materi yang termuat dalam media, ketepatan dalam pelafalan bahasa Inggris oleh pengisi suara, kemudahan dalam mengoprasikan media, kesesuaian latihan dan tugas yang diberikan pada siswa, dan daya tarik media terhadap perhatian siswa. Menurut (Gerlach \& Ely, 1971) terdapat tiga sifat yang melekat pada media yakni fiksatif, manipulatif, dan distributif. Sifat fiksatif berkaitan dengan kemampuan media memproses, menyimpan dan menampilkan informasi atau pesan pembelajaran, sifat manipulatif berkaitan dengan kemampuan media dalam memanipulasi pesan atau informasi sesuai dengan kebutuhan belajar, dan sifat distributif artinya bahwa media mampu mendistribusikan informasi secara cepat dan luas. Sifat - sifat tersebut dilekatkan agar media pembelajaran mampu membangkitkan motivasi, menimbulkan respon, digunakan secara fleksibel, dan merangsang siswa untuk mengadakan latihan (Rowntree dalam Jennah, 2009).

Media pembelajaran juga mendapatkan skor yang tinggi pada saat uji lapangan terkait penggunaan jenis font, pemilihan warna yang kontras, tampilan media dan pengoprasian yakni 189 atau $94.5 \%$ dari total skor. Levie \& Lentz, (1982) meletakkan empat fungsi dasar yang harus ada dalam media pembelajaran visual yakni fungsi atensi, fungsi afektif, fungsi kongnitif, dan fungsi kompensatoris. Fungsi atensi berarti media memiliki daya tarik untuk memfokuskan konsentrasi siswa terlibat dalam proses pembelajaran. Fungsi afektif berkaitan dengan tingkat kenyamanan siswa dalam membaca teks dan melihat gambar atau lambang visual. Fungsi kognitif berkaitan dengan aspek kebermanfaatan pengetahuan yang diperoleh oleh siswa melalui rumusan tujuan pembelajaran. Dan fungsi kompensatoris direpresentasikan oleh media yang adaptif, fleksibel, dan portabel sehingga dapat mengakomodasi perbedaan gaya belajar dan daya tangkap siswa terhadap materi. (Kemp \& Dayton, 1985) menyederhanakanya dalam tiga fungsi yakni fungsi motivatif, fungsi presentatif, dan fungsi instruktif.

Media pembelajaran berbasis sparkol videoscribe termasuk dalam media pandang dengar atau audio visual yang memiliki keunggulan dalam menyajikan gambar dan suara secara bersamaan, menarik perhatian, mengatasi keterbatasan waktu dan tempat, dan merangsang saraf kognitif dan psikomotorik (Jennah, 2009). Efektivitas media pembelajaran video didasari oleh dua teori belajar yakni Dale's Crone 
of Experience dan Brunner's Learning Theory (Hadi, 2017). Teori Dale menegaskan bahwa kombinasi dari indera pengelihatan dan pendengaran dapat meningkatkan daya ingat seseorang sekitar $50 \%$ sehingga mereka dapat mendemonstrasikan, menerapkan dan mempraktikan dengan tingkat keberhasilan yang hampir sama, yang dalam teori Brunner disebut enactive atau pengalaman langsung. Kedua teori ini berdalih bahwa semakain dilibatkan siswa dalam aktivitas pembelajaran maka semakin baik pengalaman belajar yang diperoleh oleh siswa. Penelitian mengindikasikan bahwa keterampilan khusus membutuhkan pengamatan dan praktik secara berulang - ulang dan video mengomodasi apa yang dibutuhkan oleh seseoarang untuk menguasai keterampilan (Heinich et al., 2002). Selain itu, media video dengan sajian materi yang terstruktur dapat memudahkan siswa dalam memahasi konsep (Sudiarta \& Sadra, 2016). Fungsi media video yang dijelaskan oleh para ahli seperti Levie \& Lentz, Kemp \& Dayton, Harry C. Mc. Kown, Rowntree dll telah banyak dibuktikan melalui penelitian - penelitian terdahulu seperti (Rais et al., 2020) yang menyimpulkan bahwa media video lebih efektif digunakan untuk mengajarkan pemahaman keterampilan pada siswa, (Agustriana \& Buwono, 2014) dalam eskperimennya tentang efektivitas media video untuk meningkatkan hasil belajar, dan (Wuryanti \& Kartowagiran, 2016) yang mengembangkan media video animasi untuk meningkatkan motivasi dan karakter kerja keras siswa.

Menurut (Mayer et al., 2020) terdapat enam prinsip pokok yang dapat meningkatkan efektifitas video pembelajaran yakni 1) video pengajaran menampilakan sebuah proses menulis atau menggambar objek yang sedang dipelajari, 2) video pengajaran tidak menampilkan presenter yang membelakangi layar kamera ketika sedang menjelaskan, 3) video pembelajaran melibatkan siswa dalam aktivitas pembelajaran, 4) video narasi/demonstrasi lebih baik ditampilkan dalam perspektif orang pertama, 5) video dokumenter yang menggunakan bahasa kedua atau asing lebih baik disertai dengan tulisan teks dibawah/subtitle, dan 6) video pembelajaran lebih baik tidak memuat konten secara berlebihan karena dapat membiaskan fokus pembahasan. Video pembelajaran berbasis sparkol videoscribe yang telah dikembangkan memenuhi enam prinsip pokok di atas. Prinsip pertama secara otomatis terpenuhi karena pada dasarnya output dari sparkol adalah whiteboard animation video sehingga setiap objek yang ditampilkan dalam video seolah seperti digambar atau ditulis.
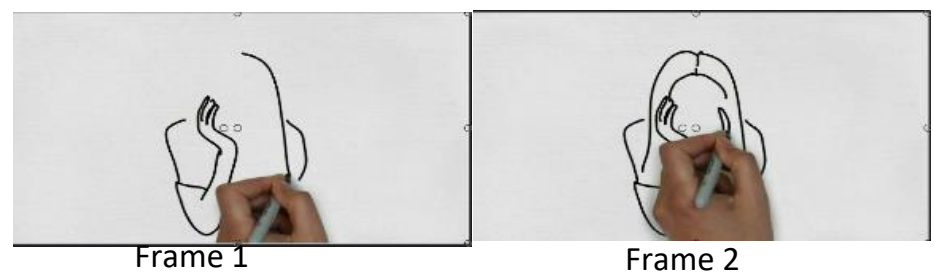

Frame 2
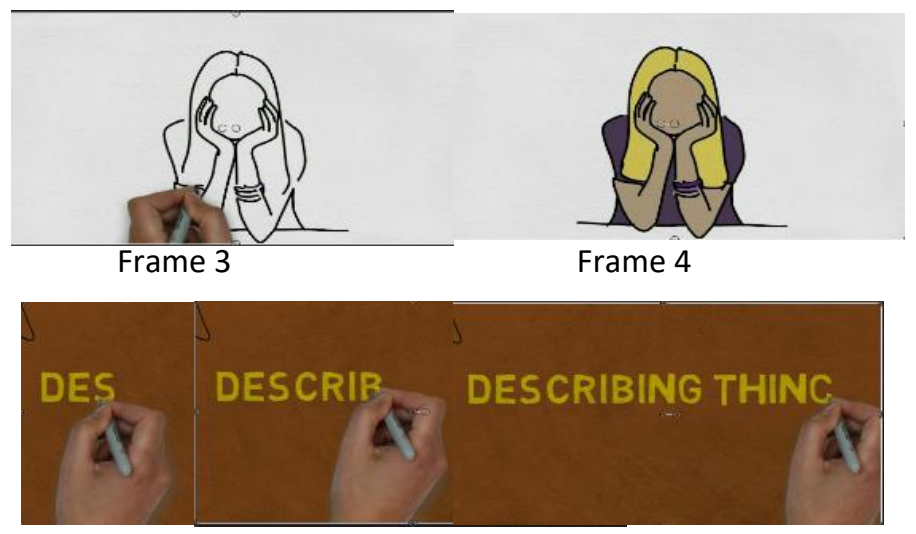

Animasi teks

Gambar 3. Screenshoot Animasi Menggambar dan Menulis dalam Sparkol 
Gambar 3 merupakan potongan adegan dalam video yang menampilkan efek animasi drawing hand terhadap objek gambar dan teks sehingga terlihat ada tangan yang menggambar atau menulis pada whiteboard. Namun efek animasi tersebut hanya digunakan pada beberapa objek tertentu yang menurut peneliti penting dan subtansial untuk diamati detailnya. Efek animasi yang digunakan diantaranya adalah move in, fade in, dan morph. Media video sparkol videoscribe tidak bersinggungan langsung dengan prinsip kedua karena hanya suara narator saja yang direkam. Namun sepintas prinsip kedua sudah diterapkan dalam beberapa potongan adegan dalam video berikut.

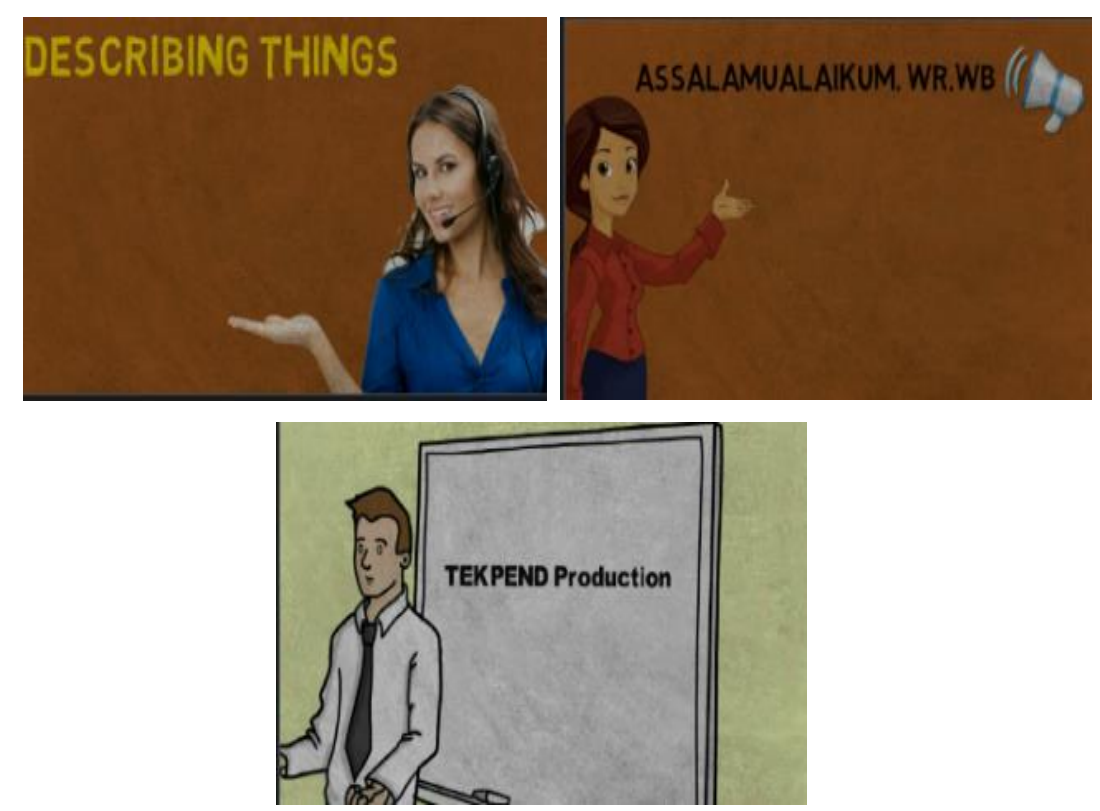

Gambar 4. Screenshoot Preseter dalam Video

Gambar 4 menunjukkan bagaimana prinsip kedua telah diterapkan dalam gambar dan teks yang termuat pada video, di mana gambar orang yang dibaratkan sebagai narator tidak membelakangi kamera utama. Gambar didukung oleh suara narator yang mengiri teks sehingga menjadi sebuah tampilan yang utuh. Penerapan prinsip ke tiga dicontohkan melalui aktivitas 1 pada Gambar 5 di mana siswa diminta untuk melanjutkan kalimat berikutnya untuk mendeskripsikan topik yang dibahas "my new backpack". Setiap pertemuan memuat aktivitas guru dan siswa yang relavan dengan pokok bahasan seperti pada aktivitas 2, di mana siswa dan guru secara bersama - sama membaca teks deskriptif sesuai dengan pelafalannya dan menjawab pertanyaan - pertanyaan terkait.
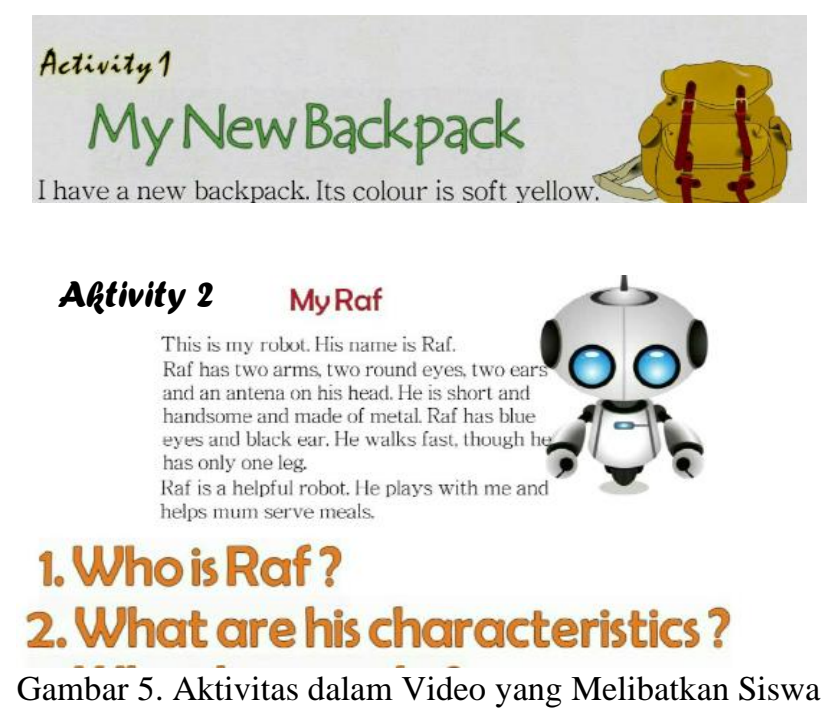

68 | Pengembangan Media Pembelajaran Berbasis Sparkol Videoscribe pada Mata Pelajaran Bahasa Inggris 
Pada aktivitas 1 siswa diminta untuk melanjutkan kalimat "I have a new backpack. Its colour is soft yellow." Guru menunjuk siswa secara acak hingga semua siswa mendapatkan giliran. Sedangkan pada aktivitas 2 siswa diminta untuk menjawab beberapa pertanyaan terkait teks deskriptif "My Raf". Prinsip ke empat secara otomatis juga diterapkan dalam media video sparkol videoscribe karena secara mendasar whiteboard animation video seperti ditunjukkan pada Gambar 6 menghasilkan video dengan pespektif orang pertama. Hal tersebut dapat dilihat dari posisi efek drawing hand yang berada di bawah layar menghadap ke arah layar, efek drawing hand pada teks yang dimulai dari kiri ke kanan, dan pada gambar yang mengikuti garis terluar gambar.

\section{\You Should Know}

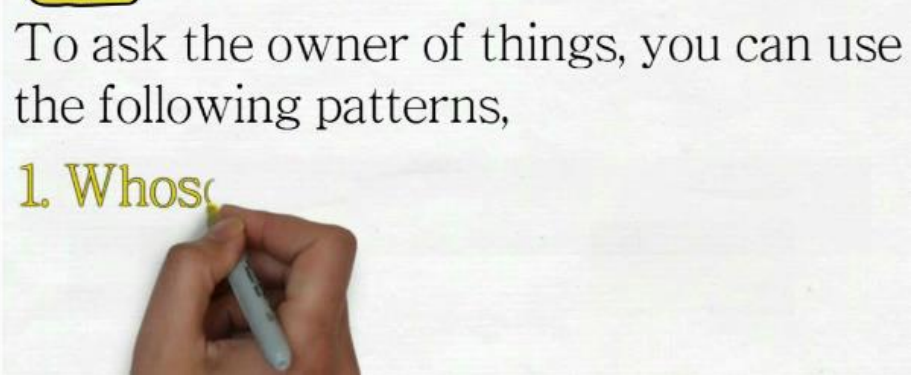

Gambar 6. Video dalam Perspektif Orang Pertama

Prinsip kelima dapat dilihat pada kegiatan conversation yang disajikan dalam video di setiap pertemuan.Gambar 7 menunjukkan prinsip kelima dimana suara percakapan dua orang diperkuat dengan gambar dan teks isi percakapan atau subtitle agar siswa dapat melakukan pengamatan terhadap pelafalan sebuah kata dengan benar.

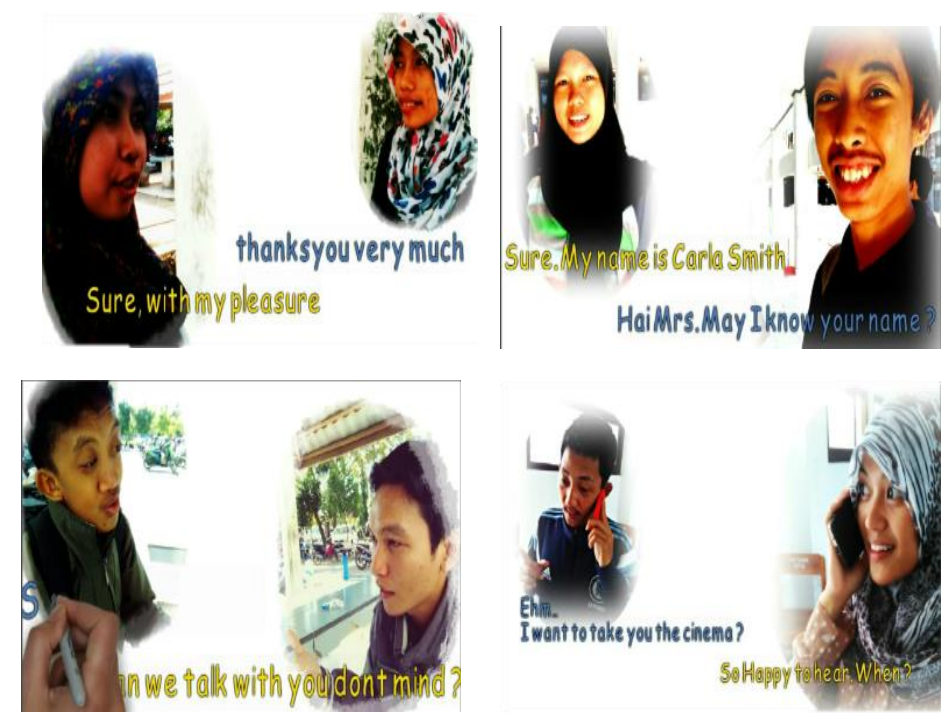

Gambar 7. Screenshoot Subtitle pada Video Pembelajaran

Prinsip terakhir yakni video tidak memuat konten secara berlebihan dapat dipastikan diterapkan dalam pengembangan videoscribe ini karena telah masuk pada kriteria validasi yang telah diajukan pada ahli. Prinsip tersebut masuk dalam pertanyaan ahli materi nomor sembilan yakni penyajian materi yang sederhana dan konkrit serta keutuhan materi. Pada lembar validasi media ada pada pertanyaan nomor tiga, lima, dan sembilan yakni kejelasan ukuran font yang digunakan, kemudahan memahami isi materi yang dijelaskan, dan daya tarik tampilan pada media. Hal tersebut dapat dilihat dalam sajian materi di pertemuan keenam yang terdiri atas pembukaan, kosakata, percakapan dan materi. 


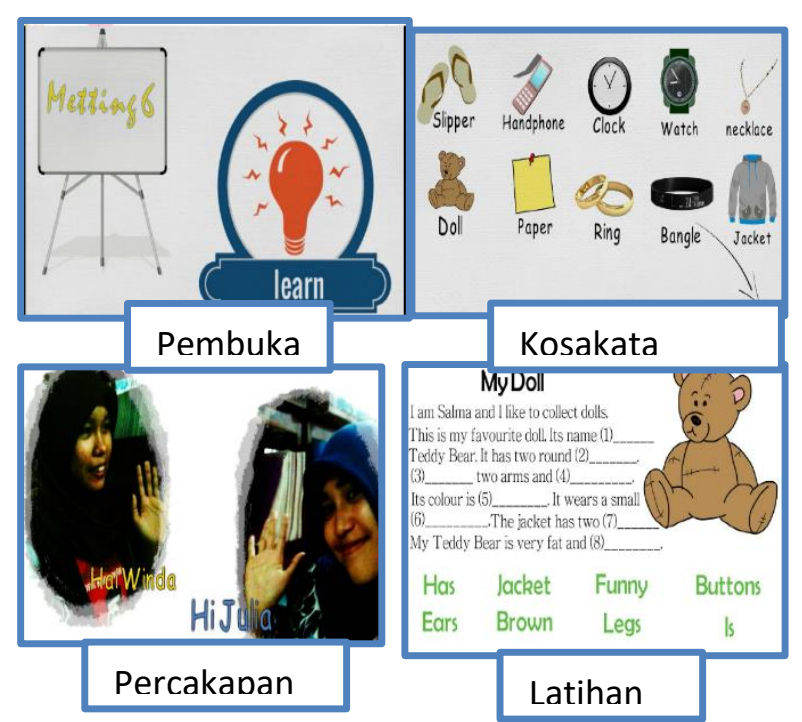

Gambar 8. Screenshoot Videoscribe di Pertemuan Keenam

Meskipun demikian ada beberapa kendala teknis maupun non teknis yang dihadapi selama proses pengembangan videoscribe. Peneliti hanya menggunakan peralatan sederhana berupa headset dan handphone untuk merekam suara sehingga kualitas suara yang dihasilkan tidak bisa sejernih suara yang direkam mengunakan alat perekam profesional dan juga perekaman dilakukan di ruangan yang tidak kedap suara sehingga terdapat suara - suara sumbang ataupun noise yang masuk dalam proses perekaman suara. Proses editing sudah dilakukan semaksimal mungkin namun noice tidak sepenuhnya dapat dihilangkan karena noise telah tercampur dengan frekuensi suara utama. Di sisi lain, peneliti yang terlibat langsung dalam proses uji lapangan sebagai seorang guru mata pelajaran merasa tidak mendalami materi secara komprehensif sehingga beberapa kali kesulitan dalam menjawab dan menjelaskan materi yang ditanyakan oleh siswa di luar dari konteks pembahasan materi. Konsekuensi tersebut diambil dengan mempertimbangkan media pembelajaran berbasis sparkol videoscribe belum disertai dengan petunjuk teknik atau pedoman penggunaan media pada waktu itu. Cahaya ruangan yang terlalu terang dan pengeras suara yang tidak menjangkau seluruh siswa yang berjumlah 40 orang sepertinya menjadi faktor - faktor lain yang dapat mempengaruhi penilaian media pada saat uji lapangan selama tujuh kali pertemuan. Perlu dicatat bahwa software Sparkol tidak menyediakan menu untuk mengedit suara sehingga peneliti kesulitan dalam menyatukan musik latar dan suara narator dengan video. Oleh karena itu, peneliti menggunakan software lain seperti Audacity untuk mengedit suara dan Camtasia untuk mengedit video lebih lanjut. Kombinasi dari ketiga software tersebut menghasilkan media pembelajaran berbasis videoscribe, di mana hasil akhir video lebih dominasi oleh karakteristik videoscribe dari Sparkol.

\section{KESIMPULAN}

Media pembelajaran berbasis Sparkol Videoscribe yang dikembangkan melalui tahapan - tahapan adaptasi Sadiman dkk (2012) yakni 1) Identifikasi Kebutuhan, 2) Perumusan Tujuan, 3) Perumusan Butir-Butir Materi, 4) Perumusan Instrumen Penilaian, 5) Penulisan Naskah Media, 6) Uji Coba, 7) Revisi, dan 8) Siap Produksi telah memenuhi kriteria kelayakan untuk digunakan pada mata pelajaran bahasa Inggris sebagai alat bantu mengajar. Kelayakan tersebut dibuktikan dengan hasil validasi ahli materi dan media yang menggolongkan media pembelajaran dalam kategori baik (tanpa revisi) dan juga dikuatkan dengan hasil ujicoba lapangan oleh guru mata pelajaran dan empat puluh siswa yang nilai rata-rata menggolongkan media pembelajaran dalam kategori sangat baik (tanpa revisi).

Kehadiran media pembelajaran berbasis sparkol videosribe diharapkan mampu menstimulus guru atau pendidik untuk tidak hanya pandai menggunakan media pembelajaran dalam kelas tetapi juga mampu membuat atau bahkan mengembangkan media pembelajaran serupa melalui perangkat lunak seperti Sparkol Videoscribe, sekaligus sebagai salah satu bentuk kesungguhan dalam meningkatkan technological competence yang telah menjadi tuntutan pembelajaran abad 21, di mana guru mampu mencari, menciptakan, memilih, dan memanfaatkan teknologi pembelajaran yang efektif dan efisien. 
Meskipun media pembelajaran berbasis sparkol videoscribe telah mendapatkan penilaian kepatutan secara ilmiah untuk digunakan dalam kelas, media pembelajaran perlu dikaji lebih jauh, terutama terkait tingkat keefektifannya terhadap motivasi, minat dan hasil belajar agar dapat diketahui tingkat signifikansinya terhadap keberhasilan proses pembelajaran. Bagi peneliti lain, kreatifitas dan keterampilan dalam mengoprasikan sparkol sangat diperhitungkan untuk menghasilkan videoscribe yang berkualitas tinggi. Di lain sisi, alat dan tempat perekaman suara juga sangat menentukan mutu media karena selain gambar, suara merupakan tumpuan utama dalam menyampaikan pesan pembelajaran.

\section{UCAPAN TERIMA KASIH}

Terima kasih banyak diucapkan kepada kepala sekolah MTsN Model Makassar yang telah mengizinkan saya untuk melakukan penelitian di kelas VII pada mata pelajaran bahasa Inggris, dan juga teman teman di program studi teknologi pendidikan yang telah meluangkan waktu, tenaga dan pikirannya untuk membantu penyelesaian penelitian ini. Semoga kebaikan selalu menyertai kita semua.

\section{DAFTAR PUSTAKA}

Agustriana, E., \& Buwono, S. (2014). Efektivitas Penggunaan Video Pembelajaran Untuk Meningkatkan Hasil Belajar Ekonomi Siswa SMA. Jurnal Pendidikan Dan Pembelajaran Khatulistiwa, 3(8).

Batubara, D. S. (2017). Kompetensi Teknologi Informasi dan Komunikasi Guru SD/MI (Potret, Faktorfaktor, dan Upaya Meningkatkannya). Muallimuna, 3(1), 48-65.

Dwi Pratiwi, E. (2016). Pengembangan Media Audio Visual Sparkol Dalam Pembelajran Mengelola Rapat Prtemuan Di LPP IPMI Kusuma Bangsa Surakarta. Jurnal Perpustakaan.Uns, 3.

Dwijayani, N. M. (2019). Development of circle learning media to improve student learning outcomes. Journal of Physics: Conference Series, 1321(2), 171-187. https://doi.org/10.1088/17426596/1321/2/022099

Fransisca, I. (2018). Pengembangan Media Pembelajaran Video Berbasis Sparkol Videoscribe Pada Pelajaran Ipa Dalam Materi Tata Surya Kelas Vi Sd. Jurnal Penelitian Pendidikan Guru Sekolah Dasar, 6(11), 1916-1927.

Gerlach, V. S., \& Ely, D. P. (1971). Teaching \& Media: A Systematic Approach. Englewood Cliffs.

Hadi, S. (2017). Efektivitas Penggunaan Video Sebagai Media Pembelajaran untuk Siswa Sekolah Dasar. Prosiding TEP \& PDs, 1(15), 96-102.

Heinich, R., Molenda, M., Russel, J., \& Smaldino, S. (2002). Instructional Media and Technologies for Learning (Seventh Ed). Pearson Education.

Jennah, R. (2009). Media Pembelajaran. Antasari Press.

Kemp, J. E., \& Dayton, D. . (1985). Planning and Producing Instructional Media. Harper \& Row Publishers.

Levie, W. H., \& Lentz, R. (1982). Effects of text illustrations: a review of research. Educational Communication and Technology Journal, 30, 195-232.

Mayer, R. E., Fiorella, L., \& Stull, A. (2020). Five ways to increase the effectiveness of instructional video. Educational Technology Research and Development, 68(3), 837-852. https://doi.org/10.1007/s11423-020-09749-6 
Nessipbayeva, O. (2019). The Competencies of the Modern Teacher. Pre-Service and In-Service Teacher Training, 148-154. http://bit.ly/2fRwNoY

Pamungkas, A. S., Ihsanudin, I., Novaliyosi, N., \& Yandari, I. A. V. (2018). Video Pembelajaran Berbasis Sparkol Videoscribe: Inovasi Pada Perkuliahan Sejarah Matematika. Prima: Jurnal Pendidikan Matematika, 2(2), 127. https://doi.org/10.31000/prima.v2i2.705

Pauwels, L. (2015). Reframing Visual Social Science: Towards a More Visual Sociology and Anthropology. Cambridge University Press.

Pineida, F. O. (2011). Competencies for the 21st century: Integrating ict to life, school and economical development. Procedia - Social and Behavioral Sciences, 28, 54-57. https://doi.org/10.1016/j.sbspro.2011.11.011

Rahim, F. R., Suherman, D. S., \& Murtiani, M. (2019). Analisis Kompetensi Guru dalam Mempersiapkan Media Pembelajaran Berbasis Teknologi Informasi Era Revolusi Industri 4.0. Jurnal Eksakta Pendidikan (Jep), 3(2), 133. https://doi.org/10.24036/jep/vol3-iss2/367

Rais, S., Verawardina, U., Ambiyar, A., Wakhinuddin, W., \& Ramadhani, D. (2020). The Effectiveness of Instructional Video Media in Coffee Knowledge Courses (Baristas). JPI (Jurnal Pendidikan Indonesia), 9(2), 258. https://doi.org/10.23887/jpi-undiksha.v9i2.24378

Richey, R. C., \& Seels, B. (1994). Defining a Field: A Case Study of the Development of the 1994 Definition of Instructional Technology. Educational media and technology yearbook.

Sadiman, Rahardjo, R., Haryono, A., \& Rahardjito. (2012). Media Pendidikan, Pengertian, Pengembangan, dan, Pemanfaatannya. Rajawali Pers.

Sudiarta, I. G. P., \& Sadra, I. P. (2016). Pengaruh Model Blended Learning berbantuan Video Animasi tehadap Kemampuan Pemecahan Masalah dan Pemahaman Konsep Siswa. Jurnal Pendidikan Dan Pengajaran, 49(2), 48-58.

Sudjana, N., \& Rivai, A. (2011). Media Pengajaran. Sinar Baru Algensindo.

Sulistyono, Y. (2016). Penyusunan Media Pembelajaran Poster Berbasis Teks: Studi Kasus Media Pembelajaran Poster Karya Mahasiswa Semester 5 Pendidikan Bahasa Indonesia UMS. Jurnal VARIDIKA, 27(2), 208-215. https://doi.org/10.23917/varidika.v27i2.1402

Wulandari, D. A. (2016). Pengembangan Media Pembelajaran Menggunakan Sparkol Videoscribe Dalam Meningkatkan Minat Belajar Siswa Pada Mata Pelajaran Ipa Materi Cahaya Kelas Viii Di Smp Negeri 01 Kerjo Tahun Ajaran 2015 2016. Unnes, 1-207.

Wuryanti, U., \& Kartowagiran, B. (2016). Pengembangan Media Video Animasi Untuk Meningkatkan Motivasi Belajar Dan Karakter Kerja Keras Siswa Sekolah Dasar. Jurnal Pendidikan Karakter, 6(2), 232-245. https://doi.org/10.21831/jpk.v6i2.12055 